\title{
Reconstructive hermeneutics in African Christology
}

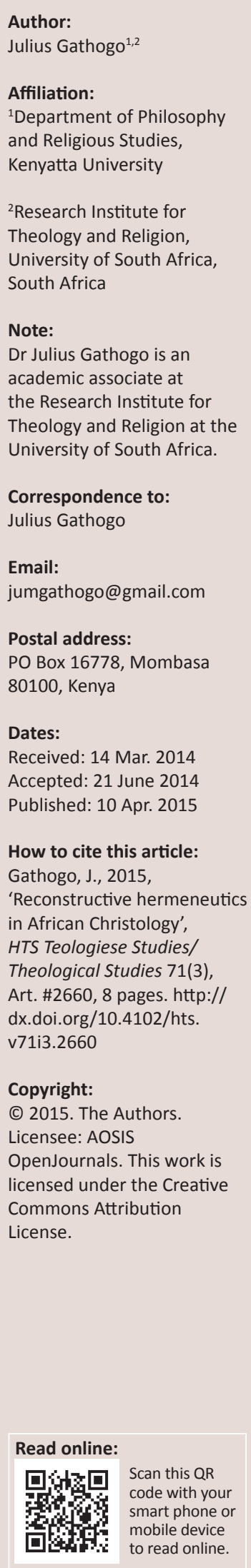

The article sets out to demonstrate African reconstructive Christology as the seventh Christological trend in African Christianity. Considering that African theology is kerygmatically universal, but theologically provincial, the study shows that Christology in our contemporary Africa can be best understood by retracing it from the early Christological controversies through to the present times. Certainly, African Christology in the 21st century is dominated by calls for contextualisation, indigenisation, rebirth, inculturation, renewal, rejuvenation, renaissance and reconstruction. To this end, the article endeavours to demonstrate that Christ, the ideal reconstructionist, the one who broke the cultural codes of his time in order to reconstruct the society, is the relevant model to our contemporary world. The article draws its theoretical framework from the works of Jesse Mugambi, Kä Mana, and Wachege, amongst other proponents of reconstructive motif in African theology. In its methodology, the article first attempts to identify some early Christological developments through to the contemporary trends. It subsequently attempts a survey of the six Christological trends of the 20th century; that is a Christological trend that commits itself to interpreting and adapting Christology to modern mentality and situation; Christologies geared exclusively to the historical Jesus; Christology that tends to uphold the Trinitarian theology; Christologies based on the proclaimed Christ and the historical Jesus; Asian Christologies of inculturation and liberation; and African Christologies of inculturation and liberation. Afterwards, it analyses Christological trends of the 21st century where a seventh dimension, African reconstructive Christology, has become the norm. In so doing, the article builds on the premise that the primary task of African Christology today is restoration.

\section{Introduction}

Christological debate is arguably the most controversial issue in church history. Consequently, various antagonistic interpretations on the person of Christ have been explored despite sometimes causing serious fractures within the church itself. With Greek philosophy becoming the normal medium for both Christian theology and works of apologetics (defences of Christianity against pagan critics) in the Roman Empire, some Christians who were influenced by Gnostic ideas denied the humanity of Christ. The Gnostics regarded him as an angelic being, bringing secret knowledge from God. The Docetics, in general, held that Jesus only 'appeared' to be human, but had no human body and did not die on the cross. Through the various church Councils (refer to the Council of Nicea of $325 \mathrm{CE}$, the Council of Ephesus of $431 \mathrm{CE}$, the Council of Chalcedon of 451 $\mathrm{CE})$, the Christian churches rejected their teachings.

Whilst Christological debates are some of the most controversial areas in church history, it is also important to underline that these controversies offer a chance for reconstructive hermeneutics for Christology. Certainly, reconstructive hermeneutics on Christology cannot be done without these controversies. In turn, reconstructive hermeneutics refer to a phenomenon where emphasis on renewal, rebirth, restoration and reconciliation are given more attention in the reinterpretation of Christology in African context. A case in point is Christ's Sermon on the Mount (Matthew 5-7), where He is seen as reconstructing the existing Jewish law, improving upon it, without necessarily ushering in another one (Matthew 5:17).

Strictly speaking, biblical hermeneutics refer to the art or technique of interpreting the biblical text in order to understand its original context and then find its contemporary meaning. Hermeneutics is derived from the Greek word $\dot{\varepsilon} \rho \mu \eta \varepsilon \varepsilon v \omega$ (hermeneuō, 'translate' or 'interpret') (Klein 2000:344). It was introduced into philosophy mainly through the title of Aristotle's work On Interpretation, commonly referred to by its Latin title De Interpretatione. It is one of the earliest (360 B.C.E) extant philosophical works in the Western tradition to deal with the relationship between language and logic in a comprehensive, explicit, and formal way. Biblical hermeneutics is the study of the principles of interpretation of the Bible. Whilst Jewish and Christian biblical hermeneutics have 
some overlap, they have distinctly different interpretive traditions (Nthamburi \& Waruta 1997:40). Zablon Nthamburi and Douglass Waruta (1997) astutely note that:

unless an African is enabled to understand scripture [read Christology] in his or her own cultural patterns, the Scripture will not only lose its validity, but its authoritative relevance as well. (n.p.)

Certainly, the Scripture can only be understood in relation to the total life of a people in any given society (Nthamburi \& Waruta 1997). Even though biblical exegetes do not necessarily claim so, most of the exegetical works is largely reconstructive as it aims at a re-reading of the text with intent of making the content relevant to the context and situation; hence making it clear to the intended recipients. Interestingly, doctrinal controversies, however theologically faulty or even 'heretical,' have tended to be largely beholden to reconstructive motif.

In particular, the Council of Nicea sought to reconstruct the controversial views of Athanasius (d. 373) and Arius (d. 336). In turn, it is imperative to appreciate that the two were theologians of Alexandria, who differed concerning the nature of the Word. Athanasius held that the Word, God's speech which took flesh in Jesus, was eternal and uncreated, and was with God in the beginning. Arius denied the equality and consubstantiality of the Word (Logos) with the Father. His adversaries accused him of bringing the son of God under the level of creatures. In its reconstructive task, the council, which had about 220-250 Christian leaders, produced a creed which defined the Divine Word as deriving from the very nature of God, and not a creature. As for the Council of Ephesus, it dealt with the case of Nestorius who taught that Jesus was actually two persons - one human, the other divine. The human person was born of Mary and the divine person was the eternal Word of God. And in her reconstructive task, the council rejected this teaching and affirmed that Jesus was one person, born of Mary, in whom God's eternal Word dwelt in intimate union. Similarly, the Council of Chalcedon rejected the teaching of Eutyches who claimed that Christ was a single person, but that he had no human nature, only a divine nature. Interestingly, his followers were called Monophysites (one nature). The council in rejecting Monophysites re-affirmed the teaching of Nicea and Ephesus regarding the true humanity of Jesus, in whom God's eternal Word took flesh. Similarly, African Christologies, despite their twofold classification of inculturation and liberation, are largely indebted to reconstructive motif as they seek to reconstruct Christology and thereby create a relevant interpretation and newer understanding in African context.

To this end, Chris Ukachukwu (2003) attempts a loose understanding of reconstructive hermeneutics in African Christology when he says:

Jesus of Nazareth, the Christ himself [is] the Master Reconstructor of both the spiritual and the social well-being of the bnaiya Israel, the simple folk of his day in the first century Palestine. (p. 4)

Similarly, Hans Dieter Betz (1999), the President of Society for New Testament Studies (Hereafter, SNTS) for 1999, 'aptly articulated the notion of reconstruction in the New Testament Studies' by arguing that:

Reconstruction is what the New Testament scholarship is all about. Indeed, the New Testament itself is the result of reconstruction. The text of the Greek New Testament has been reconstructed from thousands of manuscripts and fragments of manuscripts, a process that still continues. The same is true of the Old Testament/Hebrew Bible. The history of early Christianity must be reconstructed from widely scattered pieces of information and tradition found in the sources. The theologies of Paul and the authors of the Gospels and Acts must be reconstructed by critical analysis of the sources. Much of their meaning has been obscured by thick layers of later traditionalism and needs to be excavated to bring the original contours into focus. (p. 6)

\section{Christological approaches}

In my view, there are basically six Christological approaches of the 20th century. The first Christological trend commits itself to interpreting and adapting Christology to modern mentality and situation. And in this, five Christological perspectives are evident. That is, the cosmological perspective that bases itself on an evolutionary worldview, thereby giving the view that Christ is evolution fully accomplished. Teilhard de Chardin and Karl Rahner are its main exponents (Mooney 1965). Secondly, the anthropological, existential and personalistic perspective concerns itself with confronting modern atheistic tendencies and secularist humanism - as it expresses Christology in terms of existential and personalistic philosophies which focus on human existence. Its key proponents include Rudolf Bultmann. In turn, Bultmann ignores the historical Jesus, affirms that what we know of him is what the early church believed him to be, and that $\mathrm{He}$ existed and was crucified; and that He summons each one of us to live authentically (Bultmann 1961). Thirdly, the historical perspective puts more emphasis on the historicity of Jesus as well as of his redemptive work. The proponents of this perspective include W. Pannenberg who sees Christ as the predetermined end of history (Pannenberg 1968). Other proponents of the historical perspective include E. Schillebeeckx, who starts with Jesus of Nazareth and proceeds historically and critically employing Thomism, existentialism, linguistic philosophy and exegesis to deduce that the historical Jesus is the narration of God and the paradigm of humanity; and that Christ's pro-existence as man is the sacrament amongst us of the pro-existence of God's universal love for humanity (Schillebeeckx 1979). Fourthly, the secular perspective promulgates a Christology from below and seeks to demythologise all that is supernatural and/or divine. Schoonenberg, a key proponent of this perspective, centres his Christology on reliable human data presenting Christ as a man (not God who came down) through whom God spoke, acted and encountered humanity best (Schoonenberg 1977). Fifthly, the political perspective propagates Christology in the realm of concrete practical problems in socio-economic and political spheres. This perspective presents Christ as the answer to the liberation struggle. Its key architects are scholars such as Boff and Boff $(1987)$ and Sobrino $(1978,1987)$. 
They portray Christ who opts for the poor and the oppressed; and demand conviction and practice.

The second Christological trend is geared exclusively to the historical Jesus. In utilising the modern critical, historical and scientific studies in biblical hermeneutics, it minimises the importance of classical Christology and magisterium. It is in this trend that Christ's divinity is usually rejected; thereby reducing Jesus of Nazareth to his message, which is certainly an injustice to his personality. Its chief architects are H. Kung (1957, 1976), E. Kasemann (1968) and G. Bornkamm (1980).

The third trend conceives Christology as the upholding of Trinitarian theology, which is certainly a reaction against modern secular Christologies. In particular, Karl Barth (1963), a key proponent, stresses on Christology 'from above'. The goal of this trend is to reverse the gains of some extreme Christologies. H.U. von Balthasar $(1982,1983)$ is another proponent of this school of thought.

The fourth Christological trend is Christology based on the proclaimed Christ and the historical Jesus. It differs with Christology geared exclusively to the historical Jesus, noted earlier, because it portrays Jesus of history and the Christ of faith as one and the same person. For this trend, the correlativity involved shows that both the Jesus of history and the Christ of faith express the same reality, that is, the mystery of Christ. In their articulation, they postulate that we truly follow the way of Christ by living the kingdom of God and identifying ourselves, as Christ did, with the hungry, the sick, the social rejects and all sorts of outcasts. Theologians who follow in this category include: W. Kasper (1984) and Jurgen Moltmann $(1967,1974)$.

The fifth Christological trend comprises of the Asian Christologies of inculturation and liberation. In his book, The unknown Christ of Hinduism, Raimundo Panikkar, the chief proponent of this trend, attempts to do Christology by using Hindu cultural and religious heritage (see Panikkar 1968). To this end, he integrates Hindu worldview under the premise that the Indian cultural religiosity already contains Christian elements through which one can truly find Christ. He postulates that Christianity has a lot to learn from Hindu philosophy, and vice versa, since the two are intertwined. Another proponent of Asian Inculturationist Christologies is Stanley J. Samartha (1974). For him, the universal relevance of Christ goes beyond geographical, cultural and religious limits. With regard to Asian liberationist Christologies, Felix Wilfred (1988:321ff.) presents Jesus Christ as the exemplary liberator challenging the church to get involved in the true liberating process. Wilfred sees Christ as one who has unlimited love and compassion for the suffering and the outcasts, which is an aspect of God of the poor and the lowly (daridranarayan). To him, Christ's identification with the suffering peoples, who need liberation, is symbolised by the cross. Another Asian liberationist Christologist, Pearl Drego (1987:115ff.), sees Jesus Christ as the supportive friend of women in their quest for freedom and dignity in their respective churches. In a male-dominated Asian society where women are manipulated in practically every existential aspect, Jesus turns out as a supportive and liberating friend of all times. Similarly, Samuel Rayan (1986:360) depicts Jesus as the one who provides the pressing challenge for today to either opt for God of for Mammon. For him, it is Jesus who summons to the effect that:

Primacy be given to the quest for the justice of God's Kingdom against the injustice, inequality, oppression and misery of the rule of Caesars and Herodes and all other powers which prove themselves satanic by the deprivation, domination and wretchedness they administer as He invites us to love one another as He loved by providing the health, the bread, the rice, the liberty, the honour and the acceptance of the neglected masses of the people needed to become fully themselves and know themselves and one another as God's children. (Rayan 1986:360)

The sixth Christological trend is African Christologies. According to Wachege (1992:176), the 20th century African Christologies comprised of mainly two groups; namely: African Christologies of liberation, and Christologies of inculturation. In particular, African Christologies of liberation have affinity with those of Latin America, as propounded by Boff, Gutierrez, and Sobrino, amongst others. Interestingly, liberation Christologies in Africa are more inclined to cultural and religious values and less prone to secular and Marxist ideologies (Wachege 1992). To this end, African liberationist Christologists present Jesus as not just a liberator from oppressive dehumanising systems, but also from $\sin$ - which is arguably the root cause of alienation and oppression. Moreover, Jesus is viewed as one who died as $\mathrm{He}$ fought against injustices, oppression and dehumanisations and was subsequently raised as a fruit of struggle - a move that invites African Christians to team up and gallantly participates in Christ's liberating mission. This view of classifying African Christologies of the 20th century into two categories is further boosted by other African theologians such as Charles Nyamiti (1989) and Diane Stinton (2004), who expresses the same viewpoints.

\section{Black Christology vis-à-vis Liberation Christology in Africa}

The sixth Christological trend, African Christologies, which is our central focus in this chapter, has prepared us to consider Black Christology in South Africa and Liberation Christology in the rest of Africa. Is it any different from Asian or Latin American Christology? Does it bring out a newer dimension of understanding Christ in Africa?

Takatso Mafokeng, one of the chief proponents of Black Christology in South Africa, presents Jesus Christ as 'the answer to the South African quest and hunger for freedom and complete emancipation from the shackles of apartheid' (Wachege 1992:177). Certainly, 'Christ the liberator' is central to the Black theology of South Africa. As Allan Boesak (1977:95) says, 'God's love is an active deed of liberation manifested in divine power'. Writing before apartheid was dismantled in 1994, Boesak expresses the conviction of Black Christology in South Africa that the gospel is not silent on the 
issue of oppression. Boesak (1978) articulates this conviction when he says:

Black theology [read Christology] is a theology of liberation. By that we mean the following. Black theology believes that liberation is not only 'part of' the Gospel, or 'consistent with' the Gospel; it is the content and framework of the Gospel of Jesus Christ. Born in the community of the black oppressed, it takes seriously the black experience, the black situation. Black theology grapples with suffering and oppression; it is a cry unto God for the sake of the people. It believes that in Jesus Christ the total liberation of all people has come. (p. 9f.)

Others within Black Christology category in South Africa include Manas Buthelezi (1973) and M.G. Motlhabi (1972). As noted, they portray Jesus Christ as the ideal liberator from the shackles of apartheid. Their Christologies, thus, are centred on the black experiences.

The other category of liberation Christologies in Africa North of River Limpopo are the Christologies that incorporate the theme of liberation in not only the political issues but also in other cultural elements. Jean Marc Ela (1986), one of Africa's greatest liberation theologians of note outside South Africa, a Cameroonian and a Catholic priest, has written that:

the Bible, which speaks of God and human beings in the same breath, always includes in the deliverance of God's people their political, economic, and social liberation ... without however, it being reduced to these. (p. 90)

This view by the revered liberalist, Ela, therefore implies that inculturation in African theology is not the only requirement for an ongoing incarnation of the gospel and of Jesus Christ in the world, for if there is a 'priestly' dimension of the image of Christ as healer, there is certainly a 'prophetic' dimension to Christ as the liberator. For just as religion and society could not be separated in Christ's world, so likewise in Africa religion, as religion is coterminous with life (Waruta 1998). Another major contributor is Laurenti Magesa (1987:27) who sees Christ's action of incarnation and redemption as liberating in motif. In Christ's incarnation, 'humanity has been gratuitously assumed into the divine life and given a task: to actualise this proffered divine life by freeing itself from sin in all its forms'. He goes on to say, 'this process of freedom, of liberation, is also a process of salvation to the divine call to be Christ-like, God-like' (Magesa 1987). Likewise, Bujo, Ela, \& Hitiamana (1986:79-137) presents Jesus as the one who liberates in moral or ethical as well as in socio-economic, political and in all spheres of life. Further, African women theologians such as T. Souga, L. Tappa, M.A. Oduyoye and E. Amoah have reflected on Christ the liberator of women in particular and humanity in general (Fabella \& Oduyoye 1988). As such, Christ in his liberating role reconstructs by restoring dignity to all.

\section{African inculturation Christology: Ancestral and non-ancestral}

Apart from African liberationist Christology, the other strand of African Christology is African Inculturation
Christologies. Again, this follows in two categories; namely: ancestral and non-ancestral Christologies. Interestingly, ancestral Christologies present Christ from African ancestral worldview. One of the promoters of this view, B. Bujo propounds the idea of Christ as Proto-ancestor (Bujo 1988). That is, Christ is a unique ancestor who is indeed the source of life. His rank amongst other African ancestors therefore is uniquely the highest level. Another proponent of ancestral African Christology is J. Mutiso-Mbinda $(1979,1984)$ who argues that, as in African ancestors, Christ is the ancestor par excellence, because he is our mediator and has preceded us in passing over. And as the source of new life, he is the one in whom our common destiny is pegged on. In his book, Christ as Our Ancestor: Christology from an African perspective, Charles Nyamiti (1984) sees Christ as brother ancestor and an ancestor par excellence, since his ancestorship is rooted in the Holy Spirit, in the Father and in the Logos. Others in this category include John Pobee and E. Penoukou amongst others.

The second strand in African Inculturation Christologies is non-ancestral Christologies. The proponents of this strand endeavour to the mystery of Christ in non-ancestral terms, but with the object of doing a contextual and relevant Christology for their respective peoples. An example is K.A. Kubi (1976), whose Christological functionalities have Jesus as Mediator, Liberator, Healer, Saviour, Power, and Redeemer, amongst others. A.T. Sanon (1982) uses the African understanding of initiation rituals and biblical teachings to identify Jesus with the Head and Master of initiation. Harry Sawyerr (1968) prefers to call Christ, 'the elder Brother' rather than 'Chief' because chiefs are answerable to the council of elders. Canaan Banana (1991:3) sees Christ as N'anga (traditional herbalist). He goes on to say that Christ's healings show that He imitated the mumbo-jumbo of contemporary diviners and healers. Anne Nasimiyu-Wasike (1988:133) points out that Christ the healer, as a Christological model, is much closer to the African reality where the need to eradicate suffering is paramount. John Mbiti (1976) views Christ as the Victor who conquers evil powers feared by Africans. Christ in Mbiti's Christology is thus the guarantor of immortality. Other proponents of non-ancestral African Inculturation Christology include: Kwesi Dickson, Zablon Nthamburi, and P.N. Wachege, amongst others.

\section{A two-fold classification in African Christology?}

Perhaps it is important to ask: Is African Christology classified into two-fold Christologies of liberation versus inculturation? Whilst this could be true for the Africa of the 20th century, is it the same case for Africa in the 21st century? In her book, Jesus of Africa: Voices of Contemporary African Christology, Diane Stinton (2004:68) views African Christologies as 'naturally presented in keeping with the twofold classification of inculturation and liberation, as in the case of Charles Nyamiti's simple typology'. She quotes Nyamiti $(1989: 17,29)$ who defines Christologies of inculturation as an effort 'to incarnate the gospel message in the African cultures on the theological level', which are 'more 
numerous and in many cases relatively more profound' than those of liberation Christologies. As noted above, this is also the view of P.N. Wachege, especially with regard to the African Christologies of the 20th century. Nevertheless this argument is not accurate as far as the researches on African Christologies of the 21st century are concerned. Why?

The argument in categorising African Christologies in the two-fold category (inculturation and liberation) in the 21st century is a serious theological flaw as it fails to acknowledge that we are certainly in the era of postcolonial reconstruction. Second, in the latter part of the 20th century (1990s) reconstructive Christologies became a reality in African theology, as post-colonial reconstruction phase began. To this end, African Christology is clearly dominated by inculturation, reconciliation, liberation, and reconstruction Christologies amongst others. Again, it is critical to appreciate that even though liberation and inculturation can be said to be some of the widely published paradigms in African Christianity, since the 1960s, there are other not-so-commonly published paradigms that African Christologies falls within. They include Symbolic and oral paradigms, Charismatic, Restorative, Market-theology, and Rural-ministry paradigms amongst others (see for instance (Mugambi \& Magesa 1989).

Of great importance to note is that reconstructive Christologies, in the 21st century Africa, have become the dominant motif. In view of this, Kä Mana (1993:10ff.), the Franco-phone theologian, sees reconstructive motif as another fold which is indeed the overriding paradigm in the Africa of the 21st century. In building his case for this, he makes substantial contribution with regard to Christology and the African motifs of integrity. In particular, his works sees African Christologies of reconstruction as integrating other motifs of identity, inculturation, reconciliation and liberation thereby reconstructing Africa as well as the world, in accord with humane requirements. His political ethics has its starting-point in the Christian gospel. Mana further notes that Christ the reconstructor is a key moment in the conscience of humanity - the ethical impulse. He nevertheless remains aware of the pluralistic nature of our world and the need for a dialogical approach. He thus calls upon Christians to articulate Jesus in the public forum as the horizon before whom humanity is re-constructed Mana (1993:10ff.). The world must therefore turn to Christ the re-constructor, for as the embodiment of the logic of love; he is essential to the construction of a humane future.

In attempting to answer the question, 'who is Christ today?' Mana (1993:103-105), argues that Christ is the catalyst of reconstruction, ethical and political energy, the force of our spirit, and the power of conscience. In so doing, he rightly goes beyond the concept of Christ as just portraying the models of a life-giver, mediator, the loved one or even the leader or liberator. Christ is the very breath of radical renovation, 'Christ our breath and Christ our life' (1993:106). Kä Mana goes on to argue that to do Christology is to do ethics, and to do ethics with Christ as the centre is to reconstruct Africa from within and thereby to reconstruct the world. The African Christ is our brother who was put to death by the idols of the western world, but who is coming back to life in the process of reconstruction. He is the Egyptian who reconstructs after pharaonic Christologies (1993:74f.).

Similarly, Jesse Mugambi differs with Stinton (2004), Wachege (1992) and Nyamiti (1989) on the two-fold categorisation of African Christologies. Mugambi (1995:9) argues that such argumentation and analysis is too sharp because 'the African theologians concentrating on inculturation are also concerned with liberation, and conversely, those concentrating on liberation are also concerned with inculturation'. Additionally, he sees liberation and inculturation as just one paradigm. Whilst rightly dismissing the two-fold approach to African Christology, Mugambi however errs in viewing inculturation and liberation as one inculturation-liberation paradigm. His argumentation on this is not reasonably convincing as well; as it should not be a surprise for inculturationist to compare notes with liberationists and/or vice versa, without losing their respective identities. As Tinyiko Sam Maluleke (2000) remarks:

The so-called African theology of liberation was only one current in African theology. There were others. There was the so-called 'inculturation' current, whose precursors and inspiration were the likes of Placide Tempels' La Philosophie Bantoe (first published in 1945) Griaule's Dieu d'eau: Entretiens avec Ogotemmêli as well as the kinds of early socio-anthropological studies of African religions done by Evans-Pritchard and others. Indeed, the first generation of self-conscious and written African theology during the twentieth century was deeply influenced by these works. (p. 24)

\section{Reconstructive Motif in 'The Sermon on the Mount' (Matt. 5-7)}

Christ is as Kä Mana (1993:10) says, '[i]s a key moment in the conscience of humanity.' This therefore means that, for social reconstruction to take place, Christ the reconstructor must be the focal point - to map out the direction. Indeed, the New Testament is replete with chapters and verses, which clearly shows Christ as the reconstructor. To this end, Christ's reconstructed the theologies of the scribes, the Pharisees and the Sadducees by challenging them to shun hypocrisy (Matthew 6: 1-9, Matthew 23, Luke 18: 9-14). In particular, Jesus reconstructed the liturgy of prayer when he said:

When you pray, do not be like the hypocrites, for they love to conduct their religious functions in the open in the hope of seeking public approval ... but when you pray go into your room, close the door and pray to your father, who is unseen. But when you pray, do not keep on babbling like pagans, for they think they will be heard because of their many words. Do not be like them, for your father knows what you need before you ask him... (Matthew 6:5-8)

Christ is seen as a reconstructor in the entire Sermon on the Mount (Matthew 5-7). By saying that he has not come to abolish the law or the prophets but to fulfil them, may 
also imply that he has come to reconstruct the law and make it more responsive and relevant (Matthew 5: 17). For he could not have come to fulfil the law blindly without reconstructing some misused verses. After all, he was God (as he is today), he participated in its enactment (John 1:1) and he is able to participate in its reconstruction. As we read in Matthew 5:21, Christ sought to play his role of a reconstructor by saying:

you have heard that it was said to the people long ago, 'Do not murder ...' [Exodus 20:13]. But I tell you that anyone who is angry with his [or her] brother [or sister] will be subject to judgment.

The same pattern is repeated in other verses. For example:

it has been said, 'Anyone who divorces his wife must give her a certificate of divorce' [Deuteronomy 24:1]. But I tell you that anyone who divorces his wife, except for marital unfaithfulness, causes her to become an adulterous, and anyone who marries the divorced woman commits adultery' (Matthew 5:31-32).

Concerning the controversial law of revenge, Christ the reconstructor says:

you have heard that it was said, 'Eye for eye, and tooth for tooth' [Exodus 21:24; Lev 24:20; Deuteronomy 19:21]. But I tell you, Do not resist an evil person. If someone strikes you on the right cheek, turn to him the other also. (Matthew 5: 38-42)

Similarly, Christ gives a new dimension on the law to do with the manner of treating an enemy, he says:

you have heard that it was said, 'Love your neighbour and hate your enemy' [Leviticus 19:18]. But I tell you: Love your enemies and pray for those who persecute you ... (Matthew 5: 43-44)

He then concluded the subsection by saying 'be perfect, therefore, as your heavenly Father is perfect' Matthew 5:48) thereby equating the whole question of seeking perfection to the quest for reconstruction.

Jesus reconstructed the general mode of worship by rejecting the theologies of the time. He did this by giving parables, sayings, analogies teaching, evangelising and preaching. This is climaxed by his act of driving out those who were buying and selling in the Temple (Matthew 19:45-48), reminding them that, 'my house will be a house of prayer' (thereby quoting Isaiah 56:7). In other words, he used the same scriptures that they were using as a way of saying, 'look here, your interpretation of scripture is wrong. You need to reconstruct your hermeneutics and live by it'. All in all, Christ reconstructed the ethical issues of the day so as to make them meet the challenges of the centuries to come as they provide the ethical guidance. These ethical issues included believers and murder (Matthew 5:21f.), believers and adultery (Matthew 5:27f.), divorce (Matthew 5:31f.), oaths (Matthew 5:33), revenge (Matthew 5:38f.), ethics of handling an enemy (Matthew 5:43f.) amongst other issues. By so doing, he has provided food for thought to the Africa of the 21st century where tensions, rivalries, wars, promiscuity and general immorality have become the order of the day.

\section{African reconstructive Christologies}

In building on African reconstructive Christology, Jesse Mugambi (1995:90), sees Christ as the African guest, who in the New Testament, is portrayed as one who is always at home with all peoples, cultures and languages. His uniqueness, above other ordinary guests in the African context, is seen in his emphasis on the need to rise above ethnic, racial, class and hierarchical barriers. In particular, he came into contact with Samaritans, Roman soldiers, Syro-phoenicians, tax collectors like Zacchaeus, prostitutes, peasants, fishermen, Scribes, the powerful, the destitute, women and children. As a good African guest, Christ brings gifts. One of the best gifts $\mathrm{He}$ brought is reconciliation between humanity and the maker God; and even reconciliation between Jews and gentiles, blacks and whites, men and women, rich and poor, and so forth. St. Paul stresses this point by saying, 'if anyone is in Christ, he [or she] is a new creation; everything old has passed away: see, everything has become new!' (2 Corinthians 5:17). In his status as a unique guest, Christ refreshes as 'everything become new.'

In building on African reconstructive Christologies, Ukachukwu explains that the term reconstruction makes a deep impression on him as a 'meta-language' that challenges African theologians to discern and promote new insights and new movements that help galvanise Africans in the continent and elsewhere in the Diaspora, to regain their integrity. For him, the goal of reconstruction ought to be pursued in order to re-capture Africa's self-esteem, dignity and integrity, 'in the context of the new information and communication technology' (Ukachukwu 2003:6).

As a reconstructor, hence the restorer, Jesus calls his disciples' attention to the harmony, form and beauty found in the lilies to which no human splendour could equal even that of King Solomon (Matthew 6:28-29). He was aware of the sufferings that the people endured at the hostility of nature. He is also aware of and understands the sufferings of Africans today (Nasimiyu-Wasike 1998:133). That is, drought, floods and famine are harsh realities, which have claimed millions of African people. Christ who rebuked winds and ordered harmony and tranquillity to be restored (Mark 4: 35-45) is the one who will restore peace and harmony to the African continent and to the world at large.

As a beacon of reconstruction, Christ goes beyond the respected African elders whose reverence is seen in their ability to build up families, to shepherd them effectively and in guaranteeing their communitarian-vitalistic prosperity (Wachege 1992:205). Christ, on his part, established his family i.e. the church and stabilised it by loving it and sacrificing himself for it. He accomplished this so well that, 'better than the Kikuyu [African] elders', He became the saviour (Ephesians 5:23) who gave hope to his family (John 16:33); and this can be noted throughout the gospel (Wachege 1992:205). He fulfilled the above in his conduct, words, parables, miracles and his whole life. Indeed, by preaching 
love of neighbour (Matthew 5:22ff., 22:39; Mark 12:30; John 13:34-34), mutual forgiveness (Matthew 5:38ff.; 18:21-22; Luke 17:4; 6:27ff.) and by condemning divorce (Matthew 5:32ff., 19:3ff.; Mark 10:1ff.; Luke 16:18), He superseded our revered African elders in establishing and stabilising families, thereby becoming our model of family life.

As a reconstructionist-healer, Jesus heals individuals and societies of men and women. In his cure of the paralytic, he says, 'my son, your sins are forgiven ... stand up, take your bed and go home' (Mark 2: 5-11). In Matthew 9:27-29, we find a similar situation. Jesus the healer restored the vision of the two blind men after they affirmed that they believed in the power possessed by Christ. He touched their eyes, saying, 'According to your faith be it done to you'. Healing need not imply only personal needs and, in an African context, always implies something communal (Bujo 1998:20). Seen in this light, African nations have been injured by the effects of colonisation, slave trade, the post-colonial formation of the nation-states, neo-colonialism's - economic dependency, intertribal violence and war, the corruption of many postindependence national leaders, endless wars; civil wars, poverty, racism, manipulations by the industrialised world, political mismanagement, religious intolerance, unjust international economic systems, human-made environmental crises amongst others (Nthamburi 1991:41ff.). With all these injuries, is Christ not what Africa needs than ever before?

As a cultural reconstructionist, Christ becomes the Lord of culture, the culture itself, and even transcends it as $\mathrm{He}$ transforms it (Niebuhr 1951:10ff.). To crown it all, He teaches contextually by relating the message to the particular Jewish culture in the imperialistic Graeco-Roman setting. He gives, for instance, a contextual example of Jews and Samaritans, to show the ethnic prejudice between the two (Luke 10:25-37). In so doing, He teaches us about good neighbourliness through addressing the cultural differences that existed between the Jews and her neighbours and shows how racism, tribalism and xenophobia, which are thorny issues in Africa, can be eradicated by changing our definition and attitude towards our fellow members of the human society (Luke 10:25-37) the neighbours. Interestingly, he instructs his audience to go and do likewise, thereby, making it official to not only see our fellow members of the humanity as neighbours who should always strive to shore up one another in time of need and also to be proud of our cultural backgrounds and diversities. To this end, the disciples were not expected to denounce their cultural heritage. Rather, they were to learn to assert their heritage with due care and consideration of the cultures and religions of those to whom they preached. As in the case of Christ, St. Paul used the same approach with regard to the people he evangelised to in the Mediterranean region (Acts 17:22-34, Acts 19, 20). Without abandoning his Jewish heritage, he demonstrated how thoroughly and constructively he appreciated the people's cultures. Thus, as Mugambi (1995:90) notes:

we are all, regardless of who or what we are, urged to [reconstructively] continue to assert our cultural and religious heritage fairly, whilst respecting and appreciating the religions and cultures of those around us.

\section{Conclusion}

The article began by introducing Christological hermeneutics in Africa as that which is well rooted in church history - as Africa is part of the early theological controversies that befogged the North African Christianity. As such, the various Christological controversies by the likes of Athanasius, Arius, and Eutyches, amongst others, unconsciously set early grounds for reconstructive hermeneutics - as the church had to devise ways and means of theological restorations so as to address the damages. The article went on to survey the six Christological approaches of the 20th century. It introduced a seventh one, African reconstructive Christology. To this end, the article has demonstrated that reconstructive Christology is the trend in Africa today as it integrates other motifs without necessarily rendering them 'obsolete'. Thus, in recalling the early Christianity and/or Christologies, that arguably set the current mood, we realise that the present Christologies of identity in Africa are geared towards holistic reconstruction. As a reconstructionist thus, Christ rebuilds the many walls that beg for attention; and this is seen through his ancestorhood, healing, reconciliation, elderhood and familyhood and is present as we wrestle with the vicissitudes of life (Matthew 28:20).

\section{Acknowledgements}

I would like to thank the New Testament Society of Southern Africa under Prof. Pieter Botha for inviting me to present a paper at the University of South Africa (UNISA) during their conference that took place from 5-8 October 2010. Although it was not published in their New Testament journals, owing to its highly theological leaning as opposed to New Testament Studies, it has however, earned a place in HTS Teologiese Studies/Theological Studies. I also wish to thank the editorial team of HTS for the job well done.

\section{Competing interests}

The author declares that he has no financial or personal relationship(s) that may have inappropriately influenced him in writing this article.

\section{References}

Banana, C.S., 1991, Come and share: An introduction to Christian heology, Mambo press, Harare.

Barth, K., 1963, Evangelical theology: An introduction, Doubleday, New York.

Betz, H.D., 1999, 'Remarks of the SNTS President', in M.N. Getui, S.T. Maluleke \& J.S. Ukpong (eds.), Interpreting the New Testament in Africa, p. 6, Acton, Nairobi.

Boesak, A., 1977, Farewell to innocence: A socio-ethical study on black theology and power, Orbis Books, New York.

Boesak, A., 1978, Black theology: Black power, Mowbrays, London.

Boff, L. \& Boff, C., 1987, Introducing liberation theology, Orbis Books, New York.

Bornkamm, G., 1980, 'Presbys', in X.L. Dufuor (ed.), Dictionary of the New Testament, pp. 331-334, Geoffrey Chapman, London.

Bujo, B., 1988, 'A Christocentric ethic for Black Africa', Theology Digest 30(2).

Bujo, B., 1998, The ethical dimension of community, The African model and the dialogue between North and South, Paulines Publications Africa, Nairobi. 
Bujo, B., Ela, J.M. \& Hitiamana, J., 1986, 'Evangele et liberation: La pense de Jean-Marc Ela', in J. Kabasele et al. (eds.), Chemins de la Christologie Africaine, pp. 23-32, Desclee, Paris.

Bultmann, R., 1961, 'New Testament and theology', in H. Bartish (ed.), Kerygma and myth, pp. 116-122, Harper and Row, New York.

Buthelezi, M., 1973, 'African theology and Black theology: A search for theological method', in H.J. Becken (ed.), Relevant Theology for Africa, pp. 11-24, Lutheran Publishing House, Durban.

Drego, P., 1987, 'Values, human development and women oppression', Vidyajyoti Journal of Theological Reflection 51(4).

Ela, Jean-Mark, 1986, African cry, Orbis, Mary Knoll, New York.

Fabella, V. \& Oduyoye, M.A., 1988, With passion and compassion: Third World women doing theology, Orbis Books, New York.

Kasemann, E., 1968, The Testament of Jesus, Fortress, Philadelphia.

Klein, E., 2000, A complete etymological dictionary of the English language: dealing with the origin of words and their sense development, thus illustrating the history of civilization and culture, Elsevier, Oxford.

Kubi, K.A., 1976, 'Jesus Christ: Some Christological aspects from African perspectives', in J. Mbiti (ed.), 1976, African and Asian contributions to contemporary theology, pp. 22-31, Report of consultation held at the Ecumenical Institute, Bossey, Mimeo.

Kung, H., 1957, '“Christozentrik', in J.H. Ofer \& K. Rahner (eds.), Lexikon fur Theologie und Kirche, pp. 86-98, vol. 2, Herder, Frieburg.

Kung, H., 1976, On being a Christian, Collins, London.

Magesa, L., 1987, 'Development and development policy: J.K. Nyerere's vision for Tanzania', African Christian Studies (CHIEA) 3(4).

Maluleke, T.S., 2000, 'The Rediscovery of the agency of Africans: An emerging paradigm of post-cold war and post-apartheid black and African theology', Journal of Theology for Southern Africa 108, 24-32.

Mana, K., 1993, Théologie africaine pour temps de crise, Karthala, Paris.

Mbiti, J. (ed.), 1976, African and Asian contributions to contemporary Theology, Report of consultation held at the Ecumenical Institute, Mimeo, Bossey.

Moltmann, J., 1967, Theology of hope, SCM Press, London.

Moltmann, J., 1974, The crucified God, SCM Press, London.

Motlhabi, M.G., 1972, Essays on black theology, University Christian Movement, Johannesburg.

Mooney, C.F., 1965, Teilhard de Chardin and the mystery of Christ, Harper and Row, New York.

Mugambi, J.N.K., 1995, From liberation to reconstruction: African Christian theology after the Cold War, East African Educational Publishers, Nairobi.

Mugambi, J.N.K. \& Magesa, L. (ed.), (1989), Jesus in African Christianity: Experimentation and diversity in African Christology, pp. 1-21, Initiatives, Nairobi.

Mutiso-Mbinda, J., 1979, 'Anthropology and the paschal mystery', Spearhead 59 Ggaba Publications, Eldoret.
Mutiso-Mbinda, J., 1984, 'The Eucharist and the family - in an African setting', AMECEA Documentation service 282

Nasimiyu-Wasike, A., 1998, 'Christology and an African woman's experience', in J.N.K. Mugambi \& L. Magesa (eds.), Jesus in African Christianity: Experimentation and diversity in African Christology, p. 133, Acton, Nairobi.

Niebuhr, H.R. 1951, Christ and culture, Harper and Row, New York.

Nthamburi, Z., 1991, The African church at crossroads, Uzima, Nairobi.

Nthamburi, Z., \& Waruta, D., 1997, 'Biblical hermeneutics in African instituted churches', in H.W. Kinoti \& J.M. Waliggo (eds.), The Bible in African Christianity: Essays in biblical theology, pp. 1-18, Acton, Nairobi.

Nyamiti, C., 1984, Christ as our ancestor: Christology from an African perspective, Mambo Press, Gweru.

Nyamiti, C., 1989, 'African Christologies today', in J.N.K. Mugambi \& L. Magesa (eds.), Jesus in African Christianity: Experimentation and diversity in African Christology, pp. 17, 29, Initiatives, Nairobi.

Panikkar, R., 1968, The unknown Christ of Hinduism, Westminster, Philadelphia.

Pannenberg, W., 1968, Jesus: God and man, Westminster, Philadelphia.

Rayan, S., 1986, 'Asia and justice', Vidyajyoti: Journal of Theological Reflection, S. Arakiasamy, New Delhi.

Samartha, S.J., 1974, The Hindu response to the unbound Christ, CIS, Mandras.

Sawyerr, H., 1968, Creative Evangelism: Toward a new Christian encounter with Africa, London.

Sanon, A.T., 1982, 'Enraciner l'evangile, initiations Africaines et pedagogie de la foi', Collaboration - Rene Lunaeu, Paris.

Schillebeeckx, E., 1979, Jesus: An experiment in Christology, Seabury, New York.

Schoonenberg, P., 1977, The Christ, Sheed and Ward, London.

Sobrino, J., 1978, Christology at the crossroads: A Latin American approach, SCM Press, London.

Sobrino, J., 1987, Jesus in Latin America, Orbis Books, New York.

Stinton, D.B., 2004, Jesus of Africa: Voices of contemporary African Christology, Paulines Publications Africa, Nairobi.

Ukachukwu, C.M., 2003, Intercultural hermeneutics in Africa: Methods and approaches, Acton, Nairobi.

Von Balthasar, H.U., 1982, The glory of the Lord: A theological aesthetics, vol. 1, T \& T. Clark, Edinburgh

Von Balthasar, H.U., 1983, Does Jesus know us? Do we know Him? Ignatius, San Franscisco.

Wachege, P.N., 1992, Jesus Christ our Muthamaki (ideal elder), Phoenix, Nairobi.

Waruta, D., 1998, 'Who is Jesus Christ for Africans today? Prophet, priest, Potentate', in J.N. Mugambi \& L. Magesa (eds.), Jesus in African Christianity: Experimentation and diversity in African Christology, pp. 33-42, Acton, Nairobi.

Wilfred, F., 1988, 'The liberation profession in India and church's participation', India Theological Studies, St. Peter's Pontifical Institute of Theology, Bangalore. 